Article

\title{
Phytoestrogenic Activity of Blackcurrant Anthocyanins Is Partially Mediated through Estrogen Receptor Beta
}

\author{
Naoki Nanashima ${ }^{1, *}$ (D), Kayo Horie ${ }^{1}$ and Hayato Maeda ${ }^{2}$ \\ 1 Department of Bioscience and Laboratory Medicine, Hirosaki University Graduate School of Health \\ Sciences, 66-1 Hon-cho, Hirosaki, Aomori 036-8564, Japan; k-horie@hirosaki-u.ac.jp \\ 2 Faculty of Agriculture and Life Science, Hirosaki University, 3 Bunkyo-cho, Hirosaki, Aomori 036-8561, \\ Japan; hayatosp@hirosaki-u.ac.jp \\ * Correspondence: nnaoki@hirosaki-u.ac.jp; Tel.: +81-172-5968
}

Received: 27 November 2017; Accepted: 27 December 2017; Published: 29 December 2017

\begin{abstract}
Phytoestrogens are plant compounds with estrogenic effects found in many foods. We have previously reported phytoestrogen activity of blackcurrant anthocyanins (cyanidin-3-glucoside, cyanidin-3-rutinoside, delphinidin-3-glucoside, and delphinidin-3-rutinoside) via the estrogen receptor $(E R) \alpha$. In this study, we investigated the participation of ER $\beta$ in the phytoestrogen activity of these anthocyanins. Blackcurrant anthocyanin induced ER $\beta$-mediated transcriptional activity, and the $\mathrm{IC}_{50}$ of $\mathrm{ER} \beta$ was lower than that of $\mathrm{ER} \alpha$, indicating that blackcurrant anthocyanins have a higher binding affinity to ER $\beta$. In silico docking analysis of cyanidin and delphinidin, the core portions of the compound that fits within the ligand-binding pocket of ER $\beta$, showed that similarly to $17 \beta$-estradiol, hydrogen bonds formed with the ER $\beta$ residues Glu305, Arg346, and His475. No fitting placement of glucoside or rutinoside sugar chains within the ligand-binding pocket of ER $\beta$-estradiol complex was detected. However, as the conformation of helices 3 and 12 in ER $\beta$ varies depending on the ligand, we suggest that the surrounding structure, including these helices, adopts a conformation capable of accommodating glucoside or rutinoside. Comparison of ER $\alpha$ and ER $\beta$ docking structures revealed that the selectivity for $E R \beta$ is higher than that for $E R \alpha$, similar to genistein. These results show that blackcurrant anthocyanins exert phytoestrogen activity via ER $\beta$.
\end{abstract}

Keywords: anthocyanin; blackcurrant; estrogen receptor $\beta$; phytoestrogen

\section{Introduction}

Estrogens affect the functions of organs and tissues such as bones, blood vessels, skin, and brain, and participate in the underlying mechanisms of diseases such as metabolic syndrome [1-4]. The estrogen receptor (ER) has two subtypes, ER $\alpha$ and $E R \beta$. ER $\alpha$ is mainly present in female reproductive organs such as mammary gland and uterus, whereas ER $\beta$ is found all over the body regardless of sex. The ER $\beta$ gene was cloned in 1996 [5], and the receptor is known to be involved in several diseases such as osteoporosis [6], breast cancer [1,7,8], and obesity [9], although many functions remain unclear. Although estrogen promotes the proliferation of breast cancer cells via ER $\alpha, E R \beta$ inhibits cell proliferation. Thus, it is known that ER $\beta$ inhibits the activity of ER $\alpha[8,10]$.

Blackcurrants (Ribes nigrum L.) contain high levels of flavonoids, a group of polyphenolic compounds that includes anthocyanins and flavonols. Blackcurrants are reported to contain four anthocyanins: cyanidin-3-glucoside (C3G), cyanidin-3-rutinoside (C3R), delphinidin-3-glucoside (D3G), and delphinidin-3-rutinoside (D3R) (Figure 1). D3R and C3R are anthocyanins specific to blackcurrant [11]. Blackcurrant anthocyanins are known to have some health benefits such as amelioration of obesity and inflammation and prevention of breast cancer [12-14]. 


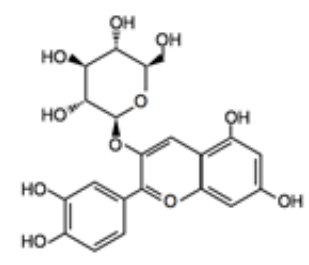

Cyanidin-3-Glucoside

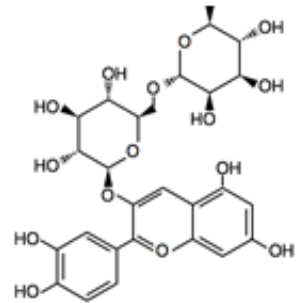

Cyanidin-3-Rutinoside

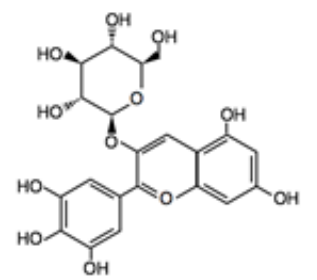

Delphinidin-3-Glucoside

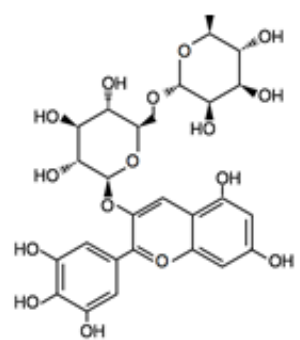

Delphinidin-3-Rutinoside

Figure 1. Chemical structures of anthocyanins derived from blackcurrant.

Phytoestrogens are a chemically diverse group of plant compounds with estrogenic effects in animals and include isoflavones, lignans, coumestans, and flavonoids; they are found in many foods [15-18]. The structure of anthocyanins is similar to that of flavanones and isoflavones. Although many health benefits of blackcurrant phytochemicals have been reported, no studies have addressed their phytoestrogenic activity. In contrast, phytoestrogen activity of the anthocyanins cyanidin and delphinidin has been reported by Schmitt et al. [19]. Recently, we have reported that these anthocyanins have a phytoestrogenic effect via ER $\alpha$ [20], but the participation of ER $\beta$ is unknown. Liquiritigenin, genistein, and S-equol are natural ligands of ER $\beta$ [21-23], and are known to inhibit the proliferation of breast, prostate, and colon cancers [24]. It is becoming clear that ER $\beta$ is involved in various diseases, and it is becoming the target of pharmacological studies [25].

To improve menopause-associated symptoms, postmenopausal women may undergo hormone replacement therapy. However, when using estrogen preparations, the risk of venous thrombosis and breast cancer must also be considered. In contrast, no association of phytoestrogens with venous thrombosis has been reported, and these compounds may suppress breast cancer. Thus, phytoestrogen is considered an important alternative to estrogen preparations [26,27].

The objective of this study was to investigate whether an anthocyanin-rich blackcurrant extract $(B C E)$ and four blackcurrant anthocyanins exert phytoestrogenic activity via ER $\beta$. We investigated ER $\beta$-mediated transactivation by blackcurrant anthocyanins. In addition, the binding ability of black currant anthocyanins to ER $\beta$ was determined using competition binding assays and in silico analysis of the docking of four anthocyanins to the ER $\beta-17 \beta$-estradiol (E2) complex. The affinity of E2 to ER $\beta$ is very similar to that of $E R \alpha$, but affinity to phytoestrogens such as genistein and S-equol is high [21,23]. Therefore, based on the interaction between genistein and ER $\alpha$ or ER $\beta$ [28], the interaction of cyanidin with $\mathrm{ER} \alpha$ or $\mathrm{ER} \beta$ was evaluated in silico.

\section{Results and Discussion}

\subsection{ER $\beta$ Transactivation Activity of Blackcurrant Anthocyanins}

Blackcurrant anthocyanins exhibited estrogenic activity in human ER $\beta$ reporter assays at $50.0 \mu \mathrm{M}$ $(p<0.05)$, whereas BCE exhibited estrogenic activity at $10.0 \mu \mathrm{g} / \mathrm{mL}(p<0.05)$, but not at $1.0 \mu \mathrm{g} / \mathrm{mL}$ (Figure 2a). BCE- and anthocyanin-mediated induction of estrogen response element-dependent luciferase activity was inhibited by co-treatment with $1 \mu \mathrm{M}$ fulvestrant (Figure $2 \mathrm{~b}$ ), indicating that these effects are ER $\beta$-mediated. These results suggest that blackcurrant anthocyanins and BCE have phytoestrogenic activity mediated via ER $\beta$ signaling. 


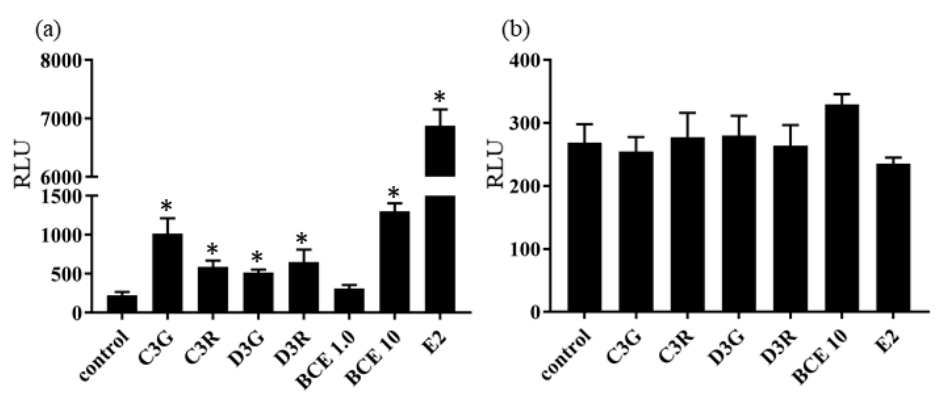

Figure 2. ER $\beta$ reporter assay of cells treated with $50 \mu \mathrm{M}$ anthocyanins and 1.0 or $10.0 \mu \mathrm{g} / \mathrm{mL}$ blackcurrant extracts (BCE) or $100 \mathrm{pM} 17 \beta$-estradiol (E2) in the absence (a) or presence (b) of $1.0 \mu \mathrm{M}$ fulvestrant for $24 \mathrm{~h}$. RLU, relative light units. Data are shown as the mean \pm standard error of the mean of at least three independent experiments. ${ }^{*} p<0.05$ vs. control.

\subsection{Binding of Blackcurrant Anthocyanins to ER $\beta$}

We next investigated whether the phytoestrogenic activity of blackcurrant anthocyanins in vitro resulted from binding to ER $\beta$ using PolarScreen assays, and we calculated the approximate $\mathrm{IC}_{50}$ values. The $\mathrm{IC}_{50}$ of E2, BCE, C3G, C3R, D3G, and C3R was $3.2 \mathrm{nM}, 3.5 \mu \mathrm{g} / \mathrm{mL}, 2.8 \mu \mathrm{M}, 9.6 \mu \mathrm{M}, 9.7 \mu \mathrm{M}$, and 2.3 $\mu \mathrm{M}$, respectively (Figure 3). BCE and the four blackcurrant anthocyanins exhibited the ability to bind to ER $\beta$. The $\mathrm{IC}_{50}$ of each anthocyanin was approximately $1 / 1000$ of that of $\mathrm{E} 2$, which is consistent with the reported much weaker effect of phytoestrogens compared to endogenous estrogen [19,20,29]. These results suggest that blackcurrant anthocyanins have a high affinity for ER $\beta$, similar to genistein, because the $\mathrm{ER} \beta \mathrm{IC}_{50}$ was lower than the $\mathrm{ER} \alpha \mathrm{IC}_{50}$ determined in our previous study [20].
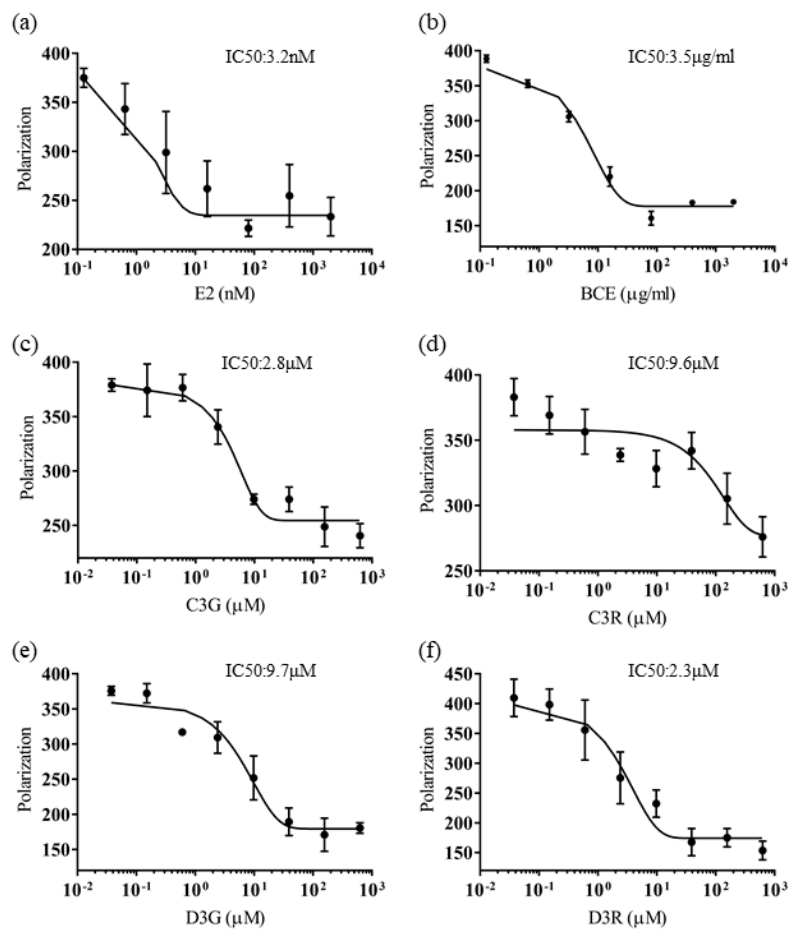

Figure 3. Competitive binding curves of blackcurrant anthocyanin-induced displacement of fluorescein-labeled $17 \beta$-estradiol (E2) from human ER $\beta$. ER $\beta$ and fluorescein-labeled estradiol were incubated for $2 \mathrm{~h}$ with a serial dilution of (a) E2; (b) blackcurrant extract; (c) cyanidin-3-glucoside (C3G); (d) cyanidin-3-rutinoside (C3R); (e) delphinidin-3-glucoside (D3G); and (f) delphinidin-3-rutinoside (D3R) at least in triplicate. $\mathrm{IC}_{50}$ corresponds to the concentration of test compound inhibiting $50 \%$ of binding of $4.5 \mathrm{nM}$ Fluormone ES2 Green to ER $\beta$. Error bars represent the standard error of the mean. 


\subsection{In Silico Docking Analysis of Estradiol and ER $\beta$}

The ligand-binding domain of ER $\beta$ formed a homodimer similar to that of ER $\alpha$, and estradiol bound inside the ligand-binding pocket of ER $\beta$. In the state with bound estradiol, helix 12 (green) was positioned in such a way as to close the ligand-binding pocket (Figure 4). Because the amino acid residues involved in the binding of estradiol to ER $\beta$ were not described by Mocklinghoff [30], the residues forming a hydrogen bond with estradiol were determined using the Swiss-PDB Viewer [31]. Like ER $\alpha$, residues Glu305, Arg346, and His475 within the binding pocket formed a hydrogen bond with estradiol in the stereostructure (PDB ID: 3OLS) of the ER $\beta$ /estradiol complex (Figure 4).

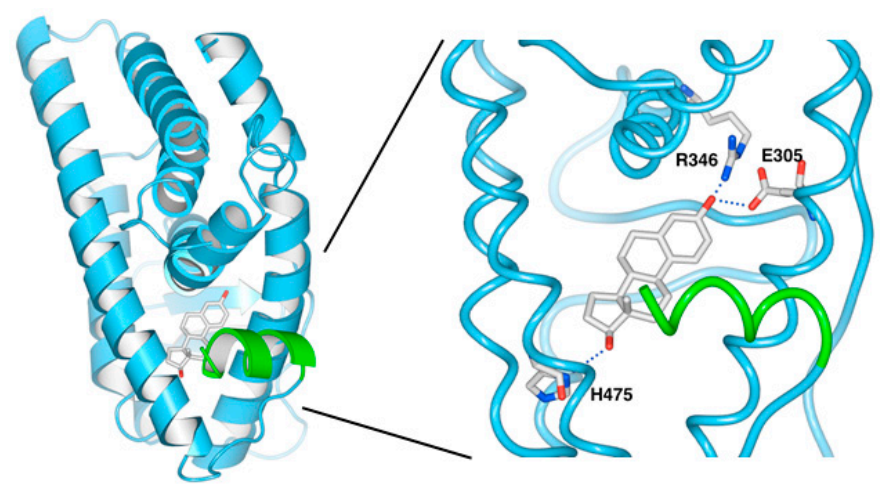

Figure 4. Ligand-binding pocket of the active ER $\beta$ conformation (PDB ID: 3OLS) showing interactions with $17 \beta$-estradiol (E2). Helix 12 is colored green.

\subsection{In Silico Docking Analysis of C3G, C3R, D3G, or D3R and ER $\beta$}

In the docking model, cyanidin and delphinidin did not collide with the amino acid residues and atoms of ER $\beta$, and fit within the internal pocket space (Figure 5a,b). Like estradiol, the hydroxyl group at position 4 of the phenyl group of cyanidin and delphinidin formed hydrogen bonds with Glu305 and Arg346 of ER $\beta$, and the hydroxyl group at position 5 of the benzopyrylium group formed a hydrogen bond with His475 of ER $\beta$ (Figure $5 a, b)$. These results suggest that cyanidin and delphinidin bind inside the binding pocket of ER $\beta$ in the same arrangement as estradiol.

Based on the docking analysis of the cyanidin and delphinidin skeletons, C3G, C3R, D3G, and $\mathrm{D} 3 \mathrm{R}$ were placed in $\mathrm{ER} \beta$, and the space where the glucose or rutinose at position 3 fits was investigated by rotating the bond with glucoside or rutinoside. Glucose or rutinose collided with amino acid residues present in helices 3 and 12, and an arrangement in which sugar chains fit in the space was not found (Figures $5 c-f$ and 6 ). These results suggest that there is not enough space inside the pocket of the ER $\beta$-estradiol complex to bind sugar chains, which is in agreement with the report by Fan et al. [32]. However, helices 3 and 12 are known to change conformation depending on the type of ligand [33-35]. Therefore, if these helices have a conformation somewhat different from that of the ER $\beta$-estradiol complex, which provides a space for accommodating sugar chains, glucoside or rutinoside may also be able to bind. Similarly, we were unable to find, using in silico docking analysis of ER $\alpha$, an arrangement in which sugar chains of glucose and rutinose bind without steric hindrance, although we have previously reported that these four anthocyanins act as agonists [20]. In ER $\beta$, it was also suggested that helices 3 and 12 form an appropriate conformation for four kinds of anthocyanins, thereby indicating that helix 12 adopts an agonist-like arrangement. 

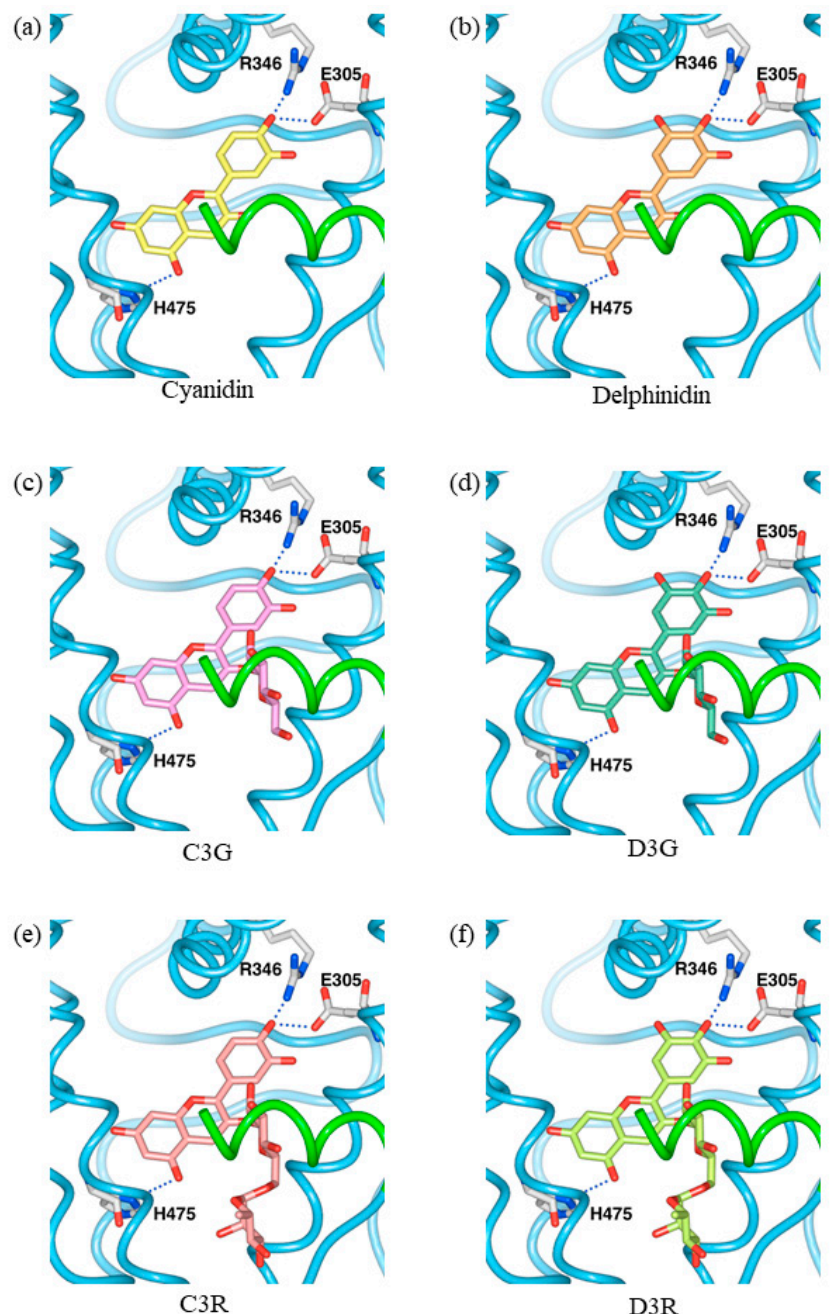

Figure 5. Ligand-binding pocket of the active ER $\beta$ conformation (PDB ID: 3OLS) showing interactions with (a) cyanidin; (b) delphinidin; (c) cyanidin-3-glucoside (C3G); (d) delphinidin-3-glucoside (D3G); (e) cyanidin-3-rutinoside (C3R) and (f) delphinidin-3-rutinoside (D3R). Helix 12 is colored green.

(a)

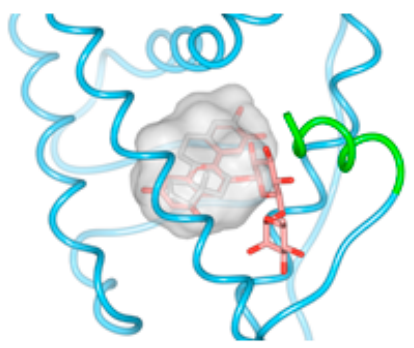

(b)

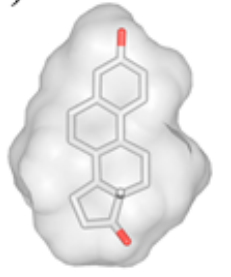

(c)

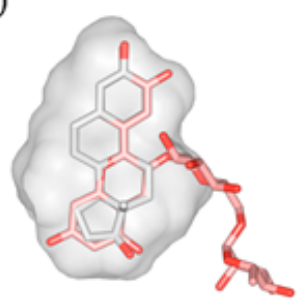

Figure 6. Interaction between the ligand-binding pocket of the ER $\beta$ and $17 \beta$-estradiol (E2) complex (PDB ID: 3OLS) and the sugar chain of cyanidin-3-rutinoside (C3R). (a) Docking model of C3R (light red) to the ER $\beta$ and estradiol complex (gray); (b) Surface shape of the binding site and appearance of E2; (c) Overlapping E2 and C3R; the sugar chain of C3R does not fit.

\subsection{Differences in Anthocyanin Binding to ER $\alpha$ and $E R \beta$}

Manas et al. have determined the conformation of the genistein/ER $\alpha$ and genistein/ER $\beta$ complexes (PDB ID: 1X7R and 1X7J) and reported the selectivity factor of genistein to ER $\beta$ [28]. To investigate the differences in anthocyanin interaction with $\mathrm{ER} \alpha$ and $\mathrm{ER} \beta$, we used $\mathrm{ER} \alpha /$ cyanidin 
and ER $\beta$ /cyanidin complex models, and each ER residue located within $5.0 \AA$ from each atom of cyanidin was determined using the Waals software. Nineteen residues were detected, and the only two residues different between ER $\alpha$ and ER $\beta$ were ER $\alpha$ Leu384 and ER $\beta$ Met336, and ER $\alpha$ Met421 and ER $\beta$ Ile373 (Figure 7a,b and Table 1). These differences are consistent with those reported in the genistein and ER $\alpha$ and ER $\beta$ binding pockets [28]. Hydrogen bonds form between cyanidin and Glu305, Arg346, and His475 of ER $\beta$, and these residues are conserved in ER $\alpha$ (Figure 7a,b and Table 1).
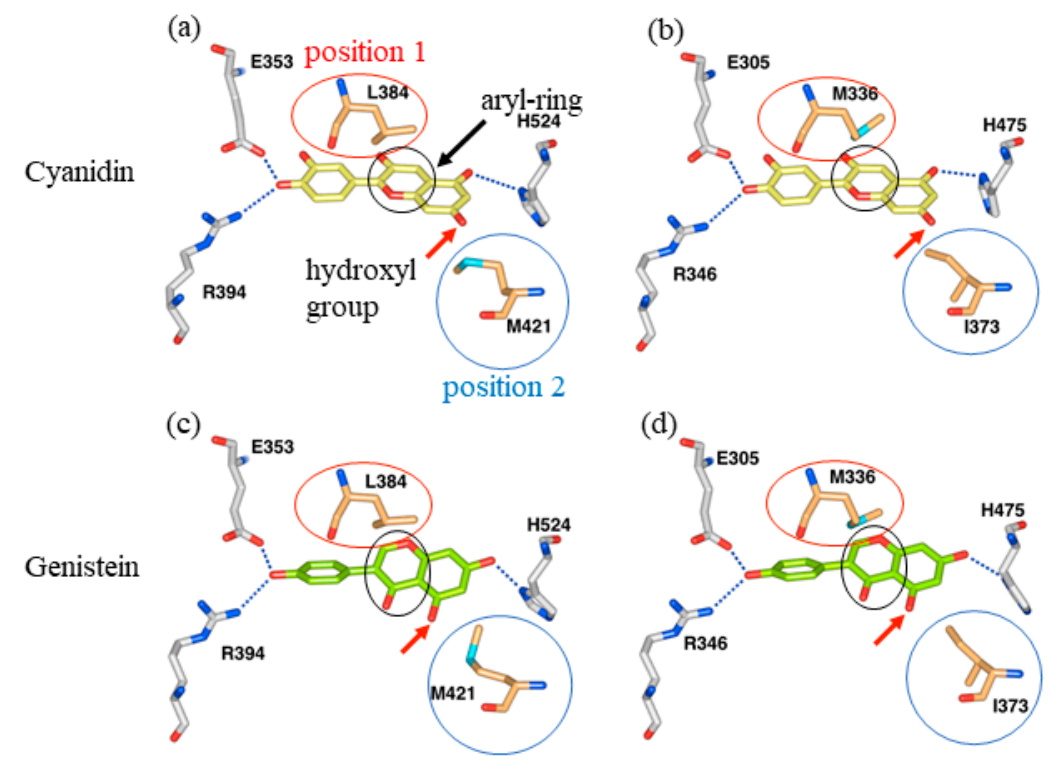

$\mathrm{ER} \alpha$

$\mathrm{ER} \beta$

Figure 7. Difference in binding affinity of cyanidin to ER $\alpha$ and ER $\beta$. Hydrogen bonds of each compound and ERs are indicated as blue dotted lines. Red, blue, and black circles indicate position 1 , position 2, and aryl ring, respectively. Red arrows indicate hydroxyl groups. (a) Interaction of cyanidin with $\mathrm{ER} \alpha$; (b) cyanidin with $\mathrm{ER} \beta$; (c) genistein with $\mathrm{ER} \alpha$; and (d) genistein with $\mathrm{ER} \beta$.

Table 1. Comparison of predicted interactions between cyanidin and ER $\alpha$ or ER $\beta$.

\begin{tabular}{|c|c|c|c|}
\hline \multicolumn{2}{|c|}{ Amino Acid Residue } & \multicolumn{2}{|c|}{ Interaction with Cyanidin } \\
\hline $\mathrm{ER} \alpha$ & $\mathrm{ER} \beta$ & Common to $\mathrm{ER} \alpha \& \mathrm{ER} \beta$ & ER $\beta$ only \\
\hline Ala350 & Ala302 & hydrophobic interaction & \\
\hline Glu353 & Glu305 & hydrogen bond & - \\
\hline Leu384 & Met336 & & interaction with aryl ring (position 1) \\
\hline Arg394 & Arg346 & hydrogen bond & - \\
\hline Phe404 & Phe356 & hydrophobic interaction & - \\
\hline Met421 & Ile373 & - & $\begin{array}{c}\text { hydrophobic interaction } \\
\text { interaction with hydroxyl group (position 2) }\end{array}$ \\
\hline His524 & His475 & hydrogen bond & - \\
\hline
\end{tabular}

Hydrophobic interactions of Ile373 in ER $\beta$, in addition to those of Ala302 and Phe356, corresponded to the interactions of Ala350 and Phe404 in ER $\alpha$, which was inferred from the complex containing cyanidin (Table 1). In this study, the positions of ER $\alpha$ Leu384 and ER $\beta$ Met336 were named position 1, and the positions of ER $\alpha$ Met421 and ER $\beta$ Ile373 were named position 2 (Figure 7).

We observed stabilization of the protein structure in an interaction between methionine and aromatic rings, called the methionine-aromatic interaction, and selectivity to ER $\beta$ in compounds having an aryl aromatic ring positioned in the B-ring of genistein (Figure 7c,d), and thus ER $\beta$ Met336 is 
estimated to have a more favorable interaction with the aryl group of genistein than ER $\alpha$ Leu384 [28]. Therefore, this interaction is considered to underlie the selectivity of genistein for ER $\beta$ rather than $\mathrm{ER} \alpha$. Cyanidin and delphinidin have aryl groups at positions corresponding to the B-ring of genistein (Figures 1 and 7a,b). Based on the report of Manas et al. we suggest that cyanidin and delphinidin can also interact more favorably with ER $\beta$ Met336 compared to ER $\alpha$ Leu384, similar to genistein [28].

There is a hydroxyl group $(5-\mathrm{OH})$ at position 5 of genistein near position 2 (Figure $7 \mathrm{c}, \mathrm{d})$. The side chain of Met421 in the ER $\alpha$ /genistein complex (PDB ID: 1X7R) adopts a rotamer whose lone pair of sulfur atoms avoids the oxygen atom of 5-OH of genistein. Furthermore, it is different from the rotamer of the side chain of Met421 of the ER $\alpha$ /estradiol complex (PDB ID: 1ERE) [30]. It is also known that dimethylsulfide clearly repels hydroxyl groups and that propane attracts weakly at an angle in which lone pairs of electrons face each other [28].

The hydroxyl group of position 7 of cyanidin is in the vicinity of ER $\alpha$ Met421 and ER $\beta$ Ile373 (Figure 7a,b). The analysis of the genistein complex suggests that the hydroxyl group at this position may repel ER $\alpha$ Met421 when binding to ER $\alpha$ (Figure 7c). In contrast, we suggest that ER $\beta$ does not repel ER $\beta$ Ile373, and the side chain of Ile373 and the carbon atoms at positions 6 and 7 may form a hydrophobic interaction (Figure 7a,b and Table 1). Therefore, ER $\beta$ Ile373 seems to be more accommodating to cyanidin and delphinidin structures than ER $\alpha$ Met421.

Given that estrogen levels decrease after menopause, dietary phytoestrogen may alleviate postmenopausal health concerns related to skin, bone, and cardiovascular heath [36-39]. In addition, it is known that E2 also affects male diseases such as benign prostatic hyperplasia and prostate cancer $[40,41]$. In particular, ER $\beta$ is expressed regardless of sex, and thus it is important to consider this receptor as a therapeutic target [25]. Furthermore, we previously orally administered BCE to female rats aged 3 weeks, and showed that BCE also had phytoestrogenic activity also in vivo [20]. We thus predict that as phytoestrogens, blackcurrant anthocyanins have many biological activities.

\section{Materials and Methods}

\subsection{Materials}

The BCE powder, CaNZac-35, was purchased from Koyo Mercantile (Tokyo, Japan). BCE contains high concentrations of polyphenols (37.6 g/100 g BCE) and anthocyanins (38.0 g/100 g BCE) [20]. C3G, C3R, D3G, and D3R (see Figure 1 for chemical structures) were purchased from Nagara Science (Gifu, Japan). E2 and fulvestrant (ICI 182,780) were purchased from Sigma-Aldrich (St. Louis, MO, USA).

\subsection{ER Transactivation Assays}

To assess the activation of human ER $\beta$, nuclear receptor transactivation assay kits were obtained from Indigo Biosciences (State College, PA, USA). Briefly, the test compounds were prepared and diluted in a medium provided by the manufacturer. The cell recovery medium provided in the assay kit was thawed, warmed to $37^{\circ} \mathrm{C}$, and added to the frozen reporter cells. The cell suspension $(100 \mu \mathrm{L})$ was dispensed into the wells of a 96-well assay plate and the test compounds $(100 \mu \mathrm{L})$ were added to the cells at the indicated concentrations and incubated for $24 \mathrm{~h}$. Luciferase activity was quantified using a TriStar LB941 multimode plate-reader (Berthold Technologies, Bad Wildbad, Germany).

\subsection{Competitive Binding Assays}

Competitive binding assays were performed using the PolarScreen ER $\beta$ Competitive Binding Assay Kit Green (Life Technologies, Carlsbad, CA, USA) according to the manufacturer's protocol. Recombinant human ER $\beta$ (23 nM) and $4.5 \mathrm{nM}$ Fluormone ES2 Green (fluorescently labeled estradiol) were incubated for $2 \mathrm{~h}$ with the test compounds. Fluorescence polarization was measured using a Flex Station 3 (Molecular Devices, Sunnyvale, CA, USA). Approximate IC $_{50}$ values, which indicate the ligand concentration that yields $50 \%$ inhibition of Fluormone ES2 Green, were determined from 
competitive binding curves generated using GraphPad Prism ver. 7.03 for Windows (GraphPad Software, San Diego, CA, USA).

\subsection{Molecular Docking Simulations}

In silico docking analysis was performed to investigate the interactions between blackcurrant anthocyanins and ER $\beta$. The interaction between E2 and ER $\beta$ was used as positive control. The steric structures of C3G and C3R were obtained from the ZINC (http://zinc.docking.org) compound database (AC4097706 and AC4097715, respectively). D3G and D3R steric structure models were constructed using MarvinSketch (ChemAxon http://www.chemaxon.com/products/marvin/) based on the structures of C3G and C3R, respectively. Docking models based on the X-ray crystal structure of human ER $\beta$ with E2 were obtained from the Protein Data Bank (PDB) (http:/ / www.rcsb.org/pdb/) (PDB ID: 3OLS) [35], which enabled analysis of docking to the active type (with E2) of ER. The steric structures of anthocyanins were fitted to the ER steric structure by superimposition on the molecular frame structure of E2 using Waals (Altif Laboratories, Tokyo, Japan). Hydrogen bonding and atomic interactions were determined using Swiss-Pdb Viewer programs available at http://swissmodel.expasy.org/. These analyses were performed at Altif Labs.

\subsection{Statistical Analysis}

Results are expressed as the mean \pm standard error of the mean (SEM) of at least three independent experiments. Statistical analyses were performed using BellCurve for Excel ver. 2.13 software (Social Survey Research Information, Tokyo, Japan) and Kruskal-Wallis analysis with the Steel post-hoc test; $p<0.05$ was considered to indicate statistical significance.

\section{Conclusions}

We investigated the possibility of blackcurrant anthocyanins binding to ER $\beta$. The results show that these anthocyanins induced ER $\beta$ transcriptional activity, and that the $\mathrm{IC}_{50}$ was smaller for ER $\beta$ than for ER $\alpha$. Consistent with these results, the affinity for ER $\beta$ was higher than that for ER $\alpha$. In the structure of the ER $\beta$ /estradiol complex, some steric hindrance was found between sugar chain atoms and helices 3 and 12. However, as the conformation of these helices varies dynamically, we suggest that when each of the four blackcurrant anthocyanins bind to ER $\beta$, they adopt a conformation suitable for accommodating glucoside or rutinoside. These results reveal that blackcurrant anthocyanins have phytoestrogen activity via ER $\beta$. Therefore, blackcurrant anthocyanins may be effective for improvement of various senile-stage disorders known to be associated with ER $\beta$, such as menopausal disorder and breast cancer.

Acknowledgments: The authors thank Fumiko Matsuzawa (Altif Laboratories) for her support. We would like to thank Editage (www.editage.jp) for English language editing. This research is partially supported by Japan Society for the Promotion of Science KAKENHI Grant Number 16K00844, the COI Next Generation Researchers Collaborative Research Fund from Japan Science and Technology Agency, Initiative for Realizing Diversity in the Research Environment, Funds for the Development of Human Resources in Science and Technology, Ministry of Education, Culture, Sports, Science and Technology and Hirosaki University Institutional Research Grant for Young Investigators.

Author Contributions: Naoki Nanashima designed the study, performed the experiments, analyzed the data, and wrote the manuscript; Kayo Horie and Hayato Maeda contributed to analysis of the data.

Conflicts of Interest: The authors declare no conflict of interest.

\section{References}

1. Jia, M.; Dahlman-Wright, K.; Gustafsson, J.A. Estrogen receptor alpha and beta in health and disease. Best Pract. Res. Clin. Endocrinol. Metab. 2015, 29, 557-568. [CrossRef] [PubMed]

2. Lobo, R.A. Metabolic syndrome after menopause and the role of hormones. Maturitas 2008, 60, 10-18. [CrossRef] [PubMed] 
3. Prisby, R.D. Mechanical, hormonal and metabolic influences on blood vessels, blood flow and bone. J. Endocrinol. 2017, 235, R77-R100. [CrossRef] [PubMed]

4. Thornton, M.J. Estrogens and aging skin. Dermatoendocrinology. 2013, 5, 264-270. [CrossRef] [PubMed]

5. Kuiper, G.G.; Enmark, E.; Pelto-Huikko, M.; Nilsson, S.; Gustafsson, J.A. Cloning of a novel receptor expressed in rat prostate and ovary. Proc. Natl. Acad. Sci. USA 1996, 93, 5925-5930. [CrossRef] [PubMed]

6. Shearman, A.M.; Karasik, D.; Gruenthal, K.M.; Demissie, S.; Cupples, L.A.; Housman, D.E.; Kiel, D.P. Estrogen receptor beta polymorphisms are associated with bone mass in women and men: The Framingham Study. J. Bone Miner. Res. 2004, 19, 773-781. [CrossRef] [PubMed]

7. Hayashi, S.I.; Eguchi, H.; Tanimoto, K.; Yoshida, T.; Omoto, Y.; Inoue, A.; Yoshida, N.; Yamaguchi, Y. The expression and function of estrogen receptor alpha and beta in human breast cancer and its clinical application. Endocr. Relat. Cancer 2003, 10, 193-202. [CrossRef] [PubMed]

8. Lazennec, G.; Bresson, D.; Lucas, A.; Chauveau, C.; Vignon, F. ER beta inhibits proliferation and invasion of breast cancer cells. Endocrinology 2001, 142, 4120-4130. [CrossRef] [PubMed]

9. Yepuru, M.; Eswaraka, J.; Kearbey, J.D.; Barrett, C.M.; Raghow, S.; Veverka, K.A.; Miller, D.D.; Dalton, J.T.; Narayanan, R. Estrogen receptor-\{beta\}-selective ligands alleviate high-fat diet- and ovariectomy-induced obesity in mice. J. Biol. Chem. 2010, 285, 31292-31303. [CrossRef] [PubMed]

10. Williams, C.; Edvardsson, K.; Lewandowski, S.A.; Strom, A.; Gustafsson, J.A. A genome-wide study of the repressive effects of estrogen receptor beta on estrogen receptor alpha signaling in breast cancer cells. Oncogene 2008, 27, 1019-1032. [CrossRef] [PubMed]

11. Gopalan, A.; Reuben, S.C.; Ahmed, S.; Darvesh, A.S.; Hohmann, J.; Bishayee, A. The health benefits of blackcurrants. Food Funct. 2012, 3, 795-809. [CrossRef] [PubMed]

12. Lee, Y.M.; Yoon, Y.; Yoon, H.; Park, H.M.; Song, S.; Yeum, K.J. Dietary anthocyanins against obesity and inflammation. Nutrients 2017, 9, 1089. [CrossRef] [PubMed]

13. Nanashima, N.; Horie, K.; Chiba, M.; Nakano, M.; Maeda, H.; Nakamura, T. Anthocyaninrich blackcurrant extract inhibits proliferation of the MCF10A healthy human breast epithelial cell line through induction of G0/G1 arrest and apoptosis. Mol. Med. Rep. 2017, 16, 6134-6141. [PubMed]

14. Shaw, O.M.; Nyanhanda, T.; McGhie, T.K.; Harper, J.L.; Hurst, R.D. Blackcurrant anthocyanins modulate CCL11 secretion and suppress allergic airway inflammation. Mol. Nutr. Food Res. 2017, 61. [CrossRef] [PubMed]

15. Guo, D.; Wang, J.; Wang, X.; Luo, H.; Zhang, H.; Cao, D.; Chen, L.; Huang, N. Double directional adjusting estrogenic effect of naringin from Rhizoma drynariae (Gusuibu). J. Ethnopharmacol. 2011, 138, 451-457. [CrossRef] [PubMed]

16. Lee, Y.M.; Kim, J.B.; Bae, J.H.; Lee, J.S.; Kim, P.S.; Jang, H.H.; Kim, H.R. Estrogen-like activity of aqueous extract from Agrimonia pilosa Ledeb. in MCF-7 cells. BMC Complement. Altern. Med. 2012, 12, 260. [CrossRef] [PubMed]

17. Limer, J.L.; Speirs, V. Phyto-oestrogens and breast cancer chemoprevention. Breast Cancer Res. 2004, 6, 119-127. [CrossRef] [PubMed]

18. Mahmoud, A.M.; Yang, W.; Bosland, M.C. Soy isoflavones and prostate cancer: A review of molecular mechanisms. J. Steroid Biochem. Mol. Biol. 2014, 140, 116-132. [CrossRef] [PubMed]

19. Schmitt, E.; Stopper, H. Estrogenic activity of naturally occurring anthocyanidins. Nutr. Cancer 2001, 41, 145-149. [CrossRef] [PubMed]

20. Nanashima, N.; Horie, K.; Tomisawa, T.; Chiba, M.; Nakano, M.; Fujita, T.; Maeda, H.; Kitajima, M.; Takamagi, S.; Uchiyama, D.; et al. Phytoestrogenic activity of blackcurrant (Ribes nigrum) anthocyanins is mediated through estrogen receptor alpha. Mol. Nutr. Food Res. 2015, 59, 2419-2431. [CrossRef] [PubMed]

21. Kuiper, G.G.; Lemmen, J.G.; Carlsson, B.; Corton, J.C.; Safe, S.H.; van der Saag, P.T.; van der Burg, B.; Gustafsson, J.A. Interaction of estrogenic chemicals and phytoestrogens with estrogen receptor beta. Endocrinology 1998, 139, 4252-4263. [CrossRef] [PubMed]

22. Mersereau, J.E.; Levy, N.; Staub, R.E.; Baggett, S.; Zogovic, T.; Chow, S.; Ricke, W.A.; Tagliaferri, M.; Cohen, I.; Bjeldanes, L.F.; et al. Liquiritigenin is a plant-derived highly selective estrogen receptor beta agonist. Mol. Cell. Endocrinol. 2008, 283, 49-57. [CrossRef] [PubMed] 
23. Setchell, K.D.; Clerici, C.; Lephart, E.D.; Cole, S.J.; Heenan, C.; Castellani, D.; Wolfe, B.E.; Nechemias-Zimmer, L.; Brown, N.M.; Lund, T.D.; et al. S-equol, a potent ligand for estrogen receptor beta, is the exclusive enantiomeric form of the soy isoflavone metabolite produced by human intestinal bacterial flora. Am. J. Clin. Nutr. 2005, 81, 1072-1079. [PubMed]

24. Sareddy, G.R.; Vadlamudi, R.K. Cancer therapy using natural ligands that target estrogen receptor beta. Chin. J. Nat. Med. 2015, 13, 801-807. [CrossRef]

25. Warner, M.; Huang, B.; Gustafsson, J.A. Estrogen receptor beta as a pharmaceutical target. Trends Pharmacol. Sci. 2017, 38, 92-99. [CrossRef] [PubMed]

26. Moreira, A.C.; Silva, A.M.; Santos, M.S.; Sardao, V.A. Phytoestrogens as alternative hormone replacement therapy in menopause: What is real, what is unknown. J. Steroid Biochem. Mol. Biol. 2014, 143, 61-71. [CrossRef] [PubMed]

27. Wuttke, W.; Jarry, H.; Westphalen, S.; Christoffel, V.; Seidlova-Wuttke, D. Phytoestrogens for hormone replacement therapy? J. Steroid Biochem. Mol. Biol. 2002, 83, 133-147. [CrossRef]

28. Manas, E.S.; Xu, Z.B.; Unwalla, R.J.; Somers, W.S. Understanding the selectivity of genistein for human estrogen receptor-beta using X-ray crystallography and computational methods. Structure 2004, 12, 2197-2207. [CrossRef] [PubMed]

29. Matsumura, A.; Ghosh, A.; Pope, G.S.; Darbre, P.D. Comparative study of oestrogenic properties of eight phytoestrogens in MCF7 human breast cancer cells. J. Steroid Biochem. Mol. Biol. 2005, 94, 431-443. [CrossRef] [PubMed]

30. Mocklinghoff, S.; Rose, R.; Carraz, M.; Visser, A.; Ottmann, C.; Brunsveld, L. Synthesis and crystal structure of a phosphorylated estrogen receptor ligand binding domain. ChemBioChem 2010, 11, 2251-2254. [CrossRef] [PubMed]

31. Guex, N.; Peitsch, M.C.; Schwede, T. Automated comparative protein structure modeling with SWISS-MODEL and Swiss-PdbViewer: A historical perspective. Electrophoresis 2009, 30 (Suppl. 1), S162-S173. [CrossRef] [PubMed]

32. Fang, H.; Tong, W.; Shi, L.M.; Blair, R.; Perkins, R.; Branham, W.; Hass, B.S.; Xie, Q.; Dial, S.L.; Moland, C.L.; et al. Structure-activity relationships for a large diverse set of natural, synthetic, and environmental estrogens. Chem. Res. Toxicol. 2001, 14, 280-294. [CrossRef] [PubMed]

33. Bourguet, W.; Germain, P.; Gronemeyer, H. Nuclear receptor ligand-binding domains: Three-dimensional structures, molecular interactions and pharmacological implications. Trends Pharmacol. Sci. 2000, 21, 381-388. [CrossRef]

34. Bruning, J.B.; Parent, A.A.; Gil, G.; Zhao, M.; Nowak, J.; Pace, M.C.; Smith, C.L.; Afonine, P.V.; Adams, P.D.; Katzenellenbogen, J.A.; et al. Coupling of receptor conformation and ligand orientation determine graded activity. Nat. Chem. Biol. 2010, 6, 837-843. [CrossRef] [PubMed]

35. Brzozowski, A.M.; Pike, A.C.; Dauter, Z.; Hubbard, R.E.; Bonn, T.; Engstrom, O.; Ohman, L.; Greene, G.L.; Gustafsson, J.A.; Carlquist, M. Molecular basis of agonism and antagonism in the oestrogen receptor. Nature 1997, 389, 753-758. [CrossRef] [PubMed]

36. Sacks, F.M. Dietary phytoestrogens to prevent cardiovascular disease: Early promise unfulfilled. Circulation 2005, 111, 385-387. [CrossRef] [PubMed]

37. Crisafulli, A.; Altavilla, D.; Marini, H.; Bitto, A.; Cucinotta, D.; Frisina, N.; Corrado, F.; D'Anna, R.; Squadrito, G.; Adamo, E.B.; et al. Effects of the phytoestrogen genistein on cardiovascular risk factors in postmenopausal women. Menopause 2005, 12, 186-192. [CrossRef] [PubMed]

38. Lissin, L.W.; Cooke, J.P. Phytoestrogens and cardiovascular health. J. Am. Coll. Cardiol. 2000, 35, $1403-1410$. [CrossRef]

39. Sirotkin, A.V.; Harrath, A.H. Phytoestrogens and their effects. Eur. J. Pharmacol. 2014, 741, 230-236. [CrossRef] [PubMed] 
40. Carruba, G. Estrogens and mechanisms of prostate cancer progression. Ann. N. Y. Acad. Sci. 2006, 1089, 201-217. [CrossRef] [PubMed]

41. Sciarra, F.; Toscano, V. Role of estrogens in human benign prostatic hyperplasia. Arch. Androl. 2000, 44, 213-220. [PubMed]

Sample Availability: Samples of the compounds are available from the authors.

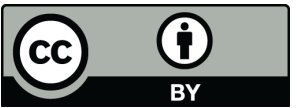

(C) 2017 by the authors. Licensee MDPI, Basel, Switzerland. This article is an open access article distributed under the terms and conditions of the Creative Commons Attribution (CC BY) license (http://creativecommons.org/licenses/by/4.0/). 